\title{
DECOLONIALITY AND "MODEL C" SCHOOLS: ETHOS, LANGUAGE AND THE PROTESTS OF 2016
}

\author{
Pam Christie \\ University of Cape Town, South Africa \\ Univeristy of Queensland, Australia \\ pam.christie@uct.ac.za

\section{Carolyn McKinney} \\ University of Cape Town, South Africa \\ carolyn.mckinney@uct.ac.za
}

\section{ABSTRACT}

This article argues that theories of "decoloniality" provide valuable insights into the social relations of "Model C" schools that have been brought into visibility in particular ways by the wave of student protests during and after 2016. Our starting point is to provide a brief outline of the central arguments made by a particular strand of theorists who have developed the term "decoloniality." We then look briefly at the history of "Model C" schools, locating their formation in the compromises of the negotiated settlement that characterised South Africa's political transition in the 1990s. We look in particular at language policy and practices in these previously white schools and at the power relations of language in South Africa. In this account, we argue that "Model C" schools exemplify the entangled power matrix that characterises coloniality. "Model C" schools, we argue, provide a clear example of how deep historical inequalities persist well past the formal end of colonialism. Pressing this argument further, we outline some possible implications for changes in schooling that a decoloniality approach invites.

Keywords: decoloniality; language policy; "Model C" schools; student protests

\section{DECOLONIALITY AND "MODEL C" SCHOOLS: ETHOS, LANGUAGE AND THE PROTESTS OF 2016}

In 2016, 20 years after the South African Schools Act ended the racially divided schooling system and established a single national system based on constitutional

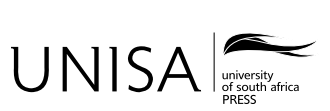

Education as Change www.educationaschange.co.za Volume 21 | Number 3 | 2017 | \#2332 | 21 pages https://doi.org/10.17159/1947-9417/2017/2332 ISSN 1947-9417 (Online), ISSN 1682-3206 (Print)

(C) 2017 The Author(s) 
principles of equality and non-discrimination, students at Pretoria High School for Girls took to social media to protest against incidents of racism, including school rules that regulated their hairstyles and excluded their use of African languages. This protest was almost immediately taken up by girls at Cape Town's Sans Souci High School who also raised complaints about demerit points being awarded for speaking isiXhosa in and out of class. Other school protests followed and the print media was filled with pictures and stories of discrimination. What was at stake in these protests was the assumption in "Model C" schools that the cultural and linguistic ethos of their historically whiteonly constituencies should continue to prevail as normative long after their student bodies had diversified. The 2016 protests were, in fact, a peak point in years of struggles against discrimination at "Model C" schools across the country, where rules controlled matters such as dress, hair (for boys and girls), headscarves, and following religious practices other than Christian. Court records show many cases of disputes over language of instruction, appointment of staff, and overt bullying of students at these schools (see Deacon 2016). These records confirm the assumption by many of the "Model C" schools that the terms of attendance at the school and the rate of change it would permit would remain firmly in the hands of those who had determined these norms in the past. This is starkly apparent in the media statement issued by the School Governing Body (SGB) of Pretoria High School for Girls in response to the Gauteng MEC's investigative report into the 2016 protests. The SGB's media statement uses a quote from the school's founding headmistress in 1902 to express the school's vision and states that the SGB "sees itself as the custodian of a tremendous legacy" (PHSG SGB 2016).

This article argues that theories of "decoloniality" provide valuable insights into the social relations of "Model C" schools that have been brought into visibility in particular ways by the wave of student struggles during and after 2016. Our starting point is to provide a brief outline of the central arguments made by a particular strand of theorists who have developed the term "decoloniality" in a specific way. We then look briefly at the history of "Model C" schools, locating their formation in the compromises of the negotiated settlement that characterised South Africa's political transition in the 1990s. ${ }^{1}$ We look in particular at language policy and practices in these previously white schools and at the power relations of language in South Africa. In this account, we argue that "Model C" schools exemplify the entangled power matrix that characterises coloniality. "Model C" schools, we argue, provide a clear example of how deep historical inequalities persist well past the formal end of colonialism. Pressing this argument further, we outline some possible implications for changes in schooling that a decoloniality approach invites.

Before expanding on these themes, it is worth noting that South Africa has a long and complex history of colonialism, briefly being colonised by the Dutch and

1 We use the term "Model C" to highlight our discomfort with a normalisation of this particular remnant of apartheid privilege. 
then the British. Consideration of this lies beyond the scope of this paper, but details are thoroughly and accessibly documented (see e.g. Giliomee and Mbenga 2007; Hamilton et al. 2012; Ross et al. 2012). Suffice it to say that from the time of white settlement after 1652, there were bitter struggles for control over land and resources, with black people living and moving in the region being violently subjugated under colonial rule. Racial hierarchies and different forms of labour control were put in place in coercive ways long before apartheid institutionalised these. For these reasons, we suggest that engagement with theories of colonialism - including internal colonialism, neo-colonialism, postcolonialism and decoloniality - is likely to yield insights and contribute to existing literature exploring inequalities of race, class, gender and locality in South African education. In this article, we suggest that theories of decoloniality, in particular, have value in understanding why school rules on matters such as hair and language are triggers of protest, 20 years after the end of apartheid. These theories provide a scaffold for thinking towards alternative schooling arrangements and a more socially just dispensation.

Both authors have done research on school desegregation in the past, and have visited "Model C" schools on a regular basis over many years while supporting student teachers during school experience placements. It has been illuminating for us to revisit and reflect on our experiences in these schools in the light of decoloniality theory and the school protests in 2016 and beyond.

\section{THEORIES OF DE/COLONIALITY}

The theories of de/coloniality that this paper draws on may be traced to the works of Latin American scholars such as Enrique Dussel (Argentina/Mexico), Anibal Quijano (Peru), Walter D. Mignolo (Argentina) and Nelson Maldonado-Torres (Puerto Rica). ${ }^{2}$ In the South African context, Sabelo Ndlovu-Gatsheni has contributed to this theoretical trajectory. Other works also form part of this oeuvre, though not necessarily using the term themselves. In the African context, these include the works of Ngũgĩ wa Thiongo, Aime Cesaire and Ali Mazrui. While recognising the importance of postcolonial theory generally and what has come to be known as "southern theory" (see Connell 2007), we do not address these theories in this paper. Suffice it to say that we endorse the position put by Ndlovu-Gatsheni (2015) that there are distinctive features that distinguish decoloniality theories from postcolonialism and other critical theories. Debating these theoretical differences lies beyond the scope of this paper.

In this section of the paper, we set out several of the key themes from the decoloniality theories we draw on. In summary, these are the distinction between "coloniality" and "colonialism," the relationship between coloniality and modernity, the intersectional inequalities that form the colonial matrix of power, the Euro-American basis of Western

2 Many of these scholars have links with universities and institutes in the US while also foregrounding their Latin American identities. 
universalism, arguments for a "pluriversalism" that includes but exceeds the Western episteme, the signal importance of language and culture, and the call for "delinking" from current geopolitical ways of knowing and thinking. To illustrate these themes, we have selected a number of direct quotations from the work of decolonial scholars where possible, so as not to "flatten out" the arguments they make through paraphrasing them too much. After setting out these themes, we show their explanatory value in understanding schooling arrangements in South Africa.

\section{Coloniality and Colonialism}

The distinctiveness of "coloniality" in relation to "colonialism" is well explained by Maldonado-Torres $(2007,243)$ as follows:

Coloniality is different from colonialism. Colonialism denotes a political and economic relation in which the sovereignty of a nation or a people rests on the power of another nation, which makes such nation an empire. Coloniality, instead, refers to long-standing patterns of power that emerged as a result of colonialism, but that define culture, labor, intersubjective relations, and knowledge production well beyond the strict limits of colonial administrations. Thus, coloniality survives colonialism. It is maintained alive in books, in the criteria for academic performance, in cultural patterns, in common sense, in the self-image of peoples, in aspirations of self, and so many other aspects of our modern experience. In a way, as modern subjects we breathe coloniality all the time and every day.

The distinction between the formal administrative structure of colonialism and the social relations generated by it is a valuable one, and we explore this further at a later point in distinguishing coloniality from neo-colonialism and postcolonialism (and implicitly, "southern theory"). The main point to establish here is the lingering nature of the multiple and entangled power relations of superiority and inferiority established under colonialism - the colonial matrix of power. The image of "breathing coloniality" conveys both the intimacy and the extent of these unequal relationships that endure beyond the dismantling of administrative structures.

\section{Coloniality and Modernity}

Latin American scholarship on de/coloniality takes the Spanish conquest of the Americas in the 1400s as a definitive moment in the constitution of a new Eurocentric world order. This period of conquest established particular forms of colonialism, and these in turn were highly significant in the development of the European Enlightenment and modernity. This period of colonisation launched early forms of capitalism on a world scale, controlled from Europe as the "centre." Maldonado-Torres (2007), building on the work of Quijano, draws attention to two major axes of power that were defined in the early colonisation of Latin America: the codification of the idea of "race" linked to inferiority/superiority and the establishment of new structures of labour control (including slavery and forms of indenture). 
Mignolo and others argue that Enlightenment thinking and modernity developed recursively in the context of colonial expansion. Writing of coloniality as "the darker side of modernity," Mignolo $(2013,98)$ states:

Modernity, usually considered to be a product of the European Renaissance or the European Enlightenment, has a darker side, which is constitutive of it. Modernity as a discourse and as a practice would not be possible without coloniality, and coloniality continues to be an inevitable outcome of modern discourses.

Ndlovu-Gatsheni $(2013,25)$, drawing on fellow decoloniality theorists, puts the position as follows:

The darker or underside of modernity included the slave trade, fratricidal colonial wars of conquest, negative development, violent civilizing missions, forcible Christianization, material dispossessions and other forms of violence. The brighter side of modernity included the flowering of individual liberties, universal suffrage, mass democracy, secularization and emancipation of the masses from the tyranny of tradition and religion, rationality and scientific spirit, popular education, technology and many other accomplishments (Boron 2005: 32). But for one to experience the darker or brighter aspects of modernity depended on which side of the abyssal lines one was located as well as the racial category into which one was classified.

In short, modernity provides a rhetoric or narrative of progress, but this cannot be replicated in all parts of the world because modernity is built on the foundations of colonialism, or, more accurately, a colonial matrix of power. This has profound implications for narratives of change and progress - including narratives of change in South Africa.

\section{Intersectional Inequalities in the Colonial Matrix of Power}

The colonial matrix of power, as explained by decoloniality theorists, is an entangled set of hierarchies, working intersectionally. Grosfuguel (2007) spells out the multiple hierarchies as follows: a particular global class formation with a diversity of labour forms; an international division of core and periphery; an interstate politico-military system controlled by Europe; a global racial/ethnic hierarchy privileging European people; a global gender hierarchy privileging European patriarchy; a sexual hierarchy privileging heterosexuals; a spiritual hierarchy privileging Christianity; an epistemic hierarchy privileging Western knowledge and cosmology; and a linguistic and cultural hierarchy privileging European languages, English especially, in communication and knowledge/theory production.

Drawing together ideas from decoloniality theorists, Mignolo $(2009,19)$ identifies four interrelated domains that make up the colonial matrix of power:

control of economy (land appropriation, exploitation of labor, control of natural resources); control of authority (institution, army); control of gender and sexuality (family, education) and control of subjectivity and knowledge (epistemology, education and formation of subjectivity). 
Specifying the entangled hierarchies in this way assists in explaining why the inequalities associated with coloniality extend beyond the dismantling of colonial administrations and have been so hard to shift.

\section{Pluriversalism and the Western Episteme}

Decoloniality theorists insist that the situatedness of knowledge be recognised. Drawing attention to the geopolitics and body politics of knowledge means that the Western episteme and its claims to universalism cannot stand unchallenged. As Mignolo (2013, n.p.) says:

Western epistemology and hermeneutics (meaning Greek and Latin languages translated into the six modern European and imperial languages) managed to universalize its own concept of universality dismissing the fact that all known civilizations are founded on the universality of [their] own cosmology.

This does not mean that the Western episteme should be simply discarded, or that forms of indigenous knowledge or precolonial knowledge systems should take centre place. What is required, rather, is an acceptance of a pluriversalist, rather than universalist approach, one that recognises that different cosmologies exist in complex and entangled power relations in the present. As Mignolo (2013) notes:

Pluriversality is not cultural relativism, but entanglement of several cosmologies connected today in a power differential. That power differential is the logic of coloniality covered up by the rhetorical narrative of modernity. Modernity is a fiction that carries in it the seed of Western pretense to universality. ... If a pluriverse is not a world of independent units (cultural relativism) but a world entangled through and by the colonial matrix of power, then, a way of thinking and understanding that dwells in the entanglement, in the borders, is needed. So the point is not to "study" the borders, very fashionable today, while at the same time "dwelling" in a territorial epistemology, [which] would imply that you accept a pluriverse [as] some place out there that you "observe" from some place else outside the pluriverse.

Decoloniality theories challenge the adequacy of describing and conceiving of the world from universalising Western perspectives, without recognising the multiple power relations that have enabled these perspectives to be imposed on other parts of the world that are then ranked as inferior. Whereas neo-colonial and postcolonial theories have developed as critical theories within EuroAmerican scholarship, decoloniality theories are concerned to delink from this scholarship, rather than reform it. They argue that this project needs to be led from border positions and the "dark side." In Mignolo's words (2007, 458),

de-coloniality, as ethically oriented, epistemically geared, politically motivated and economically necessary processes, has the damnés as its central philosophical and political figure. ... [I]f the colonizer needs to be decolonized, the colonizer may not be the proper agent of decolonization without the intellectual guidance of the damnés. 


\section{Language and Culture}

Hierarchies of language and culture are crucial aspects of the colonial matrix of power. Ngũgĩ wa Thiongo $(1986,3)$ has shown how linguistic and cultural imperialism has created a "wasteland" on the global periphery and argues that

[t]he biggest weapon wielded and actually daily unleashed by imperialism against that collective defiance is the cultural bomb. The effect of a cultural bomb is to annihilate a people's belief in their names, in their languages, in their environment, in their heritage of struggle, in their unity, in their capacities and ultimately in themselves.

It makes them see their past as one wasteland of non-achievement and it makes them want to distance themselves from that wasteland. It makes them want to identify with that which is furthest removed from themselves; for instance, with other people's languages rather than their own.

In Africa and Latin America it is commonplace for colonial languages to dominate the education system and for proficiency in a European language and script to be seen as the sole marker of being educated. It is the Western episteme that is largely responsible for monolingual myths that have underpinned research in applied linguistics and psycholinguistics (see McKinney 2017). While most children in the world grow up multilingually, theorising of language acquisition continues to assume that the typical or normal child is monolingual and acquires language sequentially in monolingual settings, as the ubiquitous terms First Language Acquisition and Second Language Acquisition illustrate (Canagarajah 2007). Eurocentric language ideologies position monolingualism in a European language as normative and privilege monolingualism over multilingualism in "other[ed]" languages. In South Africa, it is proficiency and literacy in particular forms of "standard" English that are the main marker of being educated. The dominant language ideology is Anglonormativity, "the expectation that people will be and should be proficient in English and are deficient, even deviant, if they are not" (McKinney 2017, 80). Yet, education in a foreign language or through a language in which a child is not proficient effectively removes the most valuable resource a child brings to formal schooling: their linguistic repertoire. We return to the issue of language, in particular, in addressing "Model C" schools and the student protests of 2016 .

\section{DELINKING}

The challenge posed by decoloniality theorists is the need to delink from the colonial matrix of power towards different ways of knowing and being in a liberatory project. Following Mignolo (2007, 459),

Decoloniality, then, means working toward a vision of human life that is not dependent upon or structured by the forced imposition of one ideal of society over those that differ, which is what modernity/coloniality does and, hence, where decolonization of the mind should begin. The struggle is for changing the terms in addition to the content of the conversation. 
In summary, what we have attempted to do so far in this article is to outline some of the key features of the decoloniality theories articulated primarily by a group of Latin American scholars. In using somewhat lengthy quotations from these authors, we have attempted to give a sense of the analytical approach developed within these particular theories and to enlarge on their theme that entangled hierarchies of inequalities are a continuing legacy of colonialism/modernity, long after administrative structures are dismantled or changed.

There are clear points of resonance when considering South Africa's historical legacy. As mentioned at the start of this article, from the time of white settlement after 1652, the major axes of colonialism identified by Quijano and Maldonado-Torresracial hierarchies and different structures of labour control—-were embedded in coercive if not violent ways, long before apartheid institutionalised these in a particular form of racial capitalism. The same can be said for the multiple hierarchies making up the entangled colonial power matrix outlined by Mignolo, Grosfuguel and others: control of economy, control of authority, control of gender and sexuality (family, education) and control of subjectivity and knowledge (epistemology, education and formation of subjectivity). ${ }^{3}$ Post-apartheid South Africa continues to be profoundly divided along socio-economic lines, and the wealth/poverty divide continues to overlap with racial designations for most of the population except for a small elite. Though the constitution recognises 11 official languages, in practice these do not have equal status, while in schooling, the only languages of instruction that are supported after Grade 4 are English and Afrikaans. The curriculum is firmly anchored in the trope of "powerful knowledge" in the Western episteme.

A crucial point here is the difficulty of moving beyond these multiple hierarchies towards different economic, social and epistemic power relations. A provocative but important point to consider here is the modernist rhetoric of progress and whether this is likely to be achieved within the existing power configuration, given how resilient the inequalities of apartheid/coloniality have been. Delinking from coloniality, to use Mignolo's terms, requires changing the terms of the conversation as well as its content—a radical shift.

Having set out major themes from theories of de/coloniality, we now consider the changes to schooling arrangements in South Africa after 1994 that were intended to dismantle the legacy of apartheid and lay the basis for education of equal quality for all. We show how the development and operation of "Model C" schools, and in particular their language and associated cultural practices, may be explained as forms of coloniality. Delinking from the power relations of coloniality in education, we suggest, is likely to require fundamental changes, not minor adjustments to schooling arrangements. In making these arguments about "Model C" schools, we draw on our

3 Evident in specific forms in South Africa are hierarchies of race, class, gender, sexuality, religion, language, culture and knowledge. 
own primary research in and on these schools (see Christie 1995; McKinney 2010, 2013, 2017).

\section{"MODEL C" SCHOOLS AND THE LEGACY OF APARTHEID}

How do "Model C" schools fit into the picture of decoloniality in South Africa? Part of the answer lies in understanding their origins in the end-days of the apartheid education system and their protected status in the political transition when the schooling system was being restructured after 1994. Additionally, "Model C" schools play an important hegemonic role in a narrative of progress. They are accorded the status of being the "ideal type" post-apartheid school, with the assumption that schools of this type are available for all in some unspecified future, as long as principals, teachers, students and parents work hard enough.

The establishment of Model $\mathrm{C}$ schools dates back to the dying days of apartheid, when the politically dominant National Party took steps to protect white schools- the best resourced in the system - in the face of impending change that would necessarily see the end of racially-based privilege. ${ }^{4}$ In 1990, in the context of political transition, the apartheid government developed a set of governance options for white schools that would pass substantial powers to the parent bodies of these schools and allow them to admit students of other races under strict conditions. These were the so-called "Clase Models" (named after then Minister of Education, Piet Clase), the detail of which is important for understanding how the hegemony of white control was maintained during the transition and extended under the new government of national unity after 1994.

Under Model A, the school would become fully private; under Model B it would remain a state school; and under Model $\mathrm{C}$ the school would become state-aided (or semi-private), with its management council responsible for the running of the school, appointment of staff, determination of fees and maintenance of facilities. Model C schools would receive a state subsidy to cover salaries of staff appointed within stateprescribed norms (usually amounting to about $80 \%$ of the operating expenses of schools ${ }^{5}$ ) and the management council would be responsible for raising the remaining funds. School buildings and grounds would be legally transferred to the management council free of charge, with a reversionary clause should the school cease to operate (Christie 1995, 49). Schools would need to remain majority white $(50 \%+1)$ and to give preference to white children from their feeder areas. They would have to continue to uphold principles of Christian National Education, provide mother-tongue instruction for English and Afrikaans speakers, and maintain their "traditional values and ethos." In apartheid terms, these schools would remain constitutionally bound to white education

4 This section on the "Clase Models" draws on research by Christie (1995).

5 It is interesting to note that fees have increased to such an extent in many of these schools that by 2017 government subsidy of staff and operating costs currently amounts 20 per cent or less. 
departments and would "render service" to students of other race groups provided that the schools remained fundamentally unchanged in the process.

Most white schools did not immediately avail themselves of the opportunity to desegregate, preferring instead to stay as they were. By the end of 1991, 667 schools out of a total of 2130 had transferred to Model B, 45 to Model C and one to Model $\mathrm{A}$, and 35 empty white schools were transferred to other education departments. In 1992, the government took the decisive step of declaring that all white schools would be classified as Model C. This meant that just prior to the formation of the new postapartheid government, all schools under white education departments were turned into state-aided schools, with white-controlled governing bodies having substantial powers over finances, admissions and property. During the negotiation process, the National Party government was able to protect the status of these schools, with the interim constitution stipulating that "special provisions" be made for educational institutions such as these.

The first White Paper on Education and Training (DoE 1995) had two introductions, one by Minister Bengu of the ANC and a second by Deputy Minister Schoeman of the National Party. Both introductions acknowledged the significance of the historical moment, but their approach was significantly and ominously different. For Minister Bengu (1995, n.p.), the task at hand was clear and the commitment to equity and the sharing of resources unquestionable:

It is essential for us to build a system of education and training with which all our people can identify because it serves their needs and interests. Such a system must be founded on equity and non-discrimination, it must respect diversity, it must honour learning and strive for excellence, it must be owned and cared for by the communities and stakeholders it serves, and it must use all the resources available to it in the most effective manner possible.

By contrast, Deputy Minister Schoeman (1995, n.p.) was more circumspect, focusing more on the negotiation process itself than on what an equitable education system might look like:

The road we have to travel is an uphill and rocky one - a difficult one - but the fact of the matter is that we are, as a result of a Government of National Unity and an inclusive approach in the Ministry of Education, closer than ever before to reaching a truly national consensus on the way forward in respect of education. This will dramatically increase our chances of reaching the destination of relevant, affordable, non-discriminatory, quality education for all.

While Minister Schoeman emphasises that "we" are close to "reaching a truly national consensus," what exactly "the way forward" should look like is left vague and he is convinced of only the "chances of reaching the destination" of "non-discriminatory, quality education for all." This can be interpreted as a thinly veiled admission that the National Party was on track to protect the existing position of white schools, while the goal of quality education for all was left to chance. 
The White Paper provided a broad framework for the design of a new system based on constitutional rights and the principles of reconstruction and development. In relation to governance, it positioned itself cautiously with regard to the Model $\mathrm{C}$ schools, stressing the need for democratic principles to inform consultative processes. Thus it stated $(1995,67)$ :

7. [T] he Constitution includes some "special provisions" about the governance of educational institutions. These provisions apply specifically to the rights, powers and functions which the governing bodies or similar structures of departmental, community-managed or State-aided schools possess under laws existing immediately before the Constitution came into effect. (Identical provisions apply also to universities and technikons.)

8. The national and provincial governments are required to reach agreement "by bona fide negotiations" with the respective governing bodies, and give reasonable notice, before altering the rights, powers and functions of such bodies. If agreement is not reached by negotiation, a government may nevertheless proceed to make the alterations it wishes. If it does so, however, the Constitution gives "interested persons or bodies" a specific entitlement to mount a legal challenge to the validity of such alterations in terms of the Constitution.

That the White Paper came from a government of national unity striving to build common purpose is evident in the following recognition of different conditions in schools, under the heading "The need for a managed process of change" $(1995,69)$ :

19. It is understandable that many parents, school principals, teachers and students are uncertain about what the changes in the system of education will mean for their schools and themselves. Those who are accustomed to stable schools, which have close links with the social, cultural and religious life of their communities, and honoured traditions, may feel that what is precious to them is threatened by unknown changes they may be unable to influence or control. Communities which have been favoured by the past political dispensation, and who know that a democratically elected government, representing an overwhelmingly poor electorate, cannot be expected to fund their privileges, may be particularly apprehensive about what is in store.

20. Equally, parents, teachers and students who have had to cope with appalling conditions, the result of decades of under-resourcing, instability, wasted human potential and low morale, have high expectations from a government they believe rightly is committed to redress.

Clearly, the drafters of the White Paper recognised the profound inequalities in the education system, but were not in a position to rock the "Model C" boat, and the White Paper signalled the government's willingness to compromise. The South African Schools Act (SASA) of 1996 confirmed the powers of governing bodies, including powers to set language and admissions policies provided that these were not simple proxies for race. SASA also allowed for fees to be introduced by governing bodies and for ownership of land and buildings to be passed to the school community. Technically, all state-aided schools are "public schools" and there is no such thing as "Model C." In public discourse, "Model C" has come to be used to designate former white schools, admitting students of all races under the guidance of their governing bodies. Almost all of these schools charge fees and they remain the best resourced, highest achieving public schools in the country. The very fact that these schools carry the designation — even if informally — of 
"Model C" signifies a historical link to white privilege. Decisions on key issues such as admissions, language policy and fees lie with SGBs and, as legacy white schools, the cultural and linguistic ethos of their historically white-only parent bodies has continued to prevail even as student bodies have diversified. Moreover, since "Model C" schools were in places that were formerly designated white, their location has afforded material benefits which in some cases have been quite considerable, with schools able to generate revenue by virtue of facilities and the desirability of their venues. Arguably, the market status of these schools as the best performing, well resourced schools boosts the desire to preserve their established ethos. The language policy and language regimes at these schools are significant aspects of their established ethos (see Figures 1 and 2 below).

\section{DECOLONIALITY AND LANGUAGE IN "MODEL C" SCHOOLS}

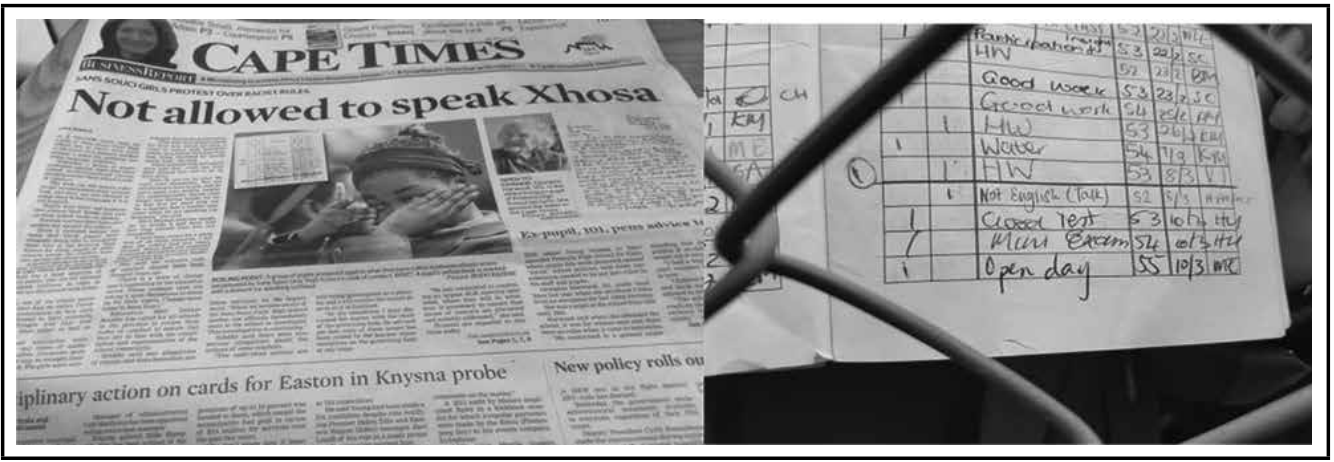

Figure 1 and 2: (On the left) A pass book image on the front page of the Cape Times, 2 September 2016; (On the right) An enlargement of the pass book image.

In relation to language, we argue that the schooling system in South Africa whether for the privileged or the poor, operates firmly within a logic of coloniality. ${ }^{6}$ Evidence of this is found in the overwhelming dominance of English, named as an Anglonormative ideology above, that pervades the schooling system. ${ }^{7}$ However, the consequences of this are quite different for children attending "Model C" and those attending more typical schools in South Africa. An African language speaking child enters a typical school and begins to learn through a named African language as home language. If they are lucky,

6 This section on language draws on research by McKinney $(2010,2013,2017)$.

7 A number of "Model C" schools were formerly Afrikaans medium schools and this status is still tightly held by the SGBs of most of these schools. Consideration of the language practices of these schools lies beyond the scope of this paper. In a few cases, provincial governments have required these schools to include English medium classes. However, SGBs of these schools have often fought, including in the courts, to maintain their language and ethos - certainly practices of coloniality. 
the language resources that they bring to school will align closely to the standard form of the African language they will use as Language of Learning and Teaching (LOLT). They take lessons in English as First Additional Language (EFAL) for 2-3 hours a week in Grade 1-2 and 3-4 hours a week in Grade 3, while using an African language as language of instruction until the end of Grade 3. Then from the beginning of Grade 4, African language speaking learners are expected to make an abrupt switch to English language of instruction in all subjects except for Home Language as a subject. All their learning materials (textbooks), workbooks and assessments are supplied in English only; they are expected to follow the same curriculum, use the same textbooks and often write the same provincially distributed tests as their English Home language peers in "Model C" schools. With insufficient proficiency in English to understand the concepts introduced in Science, Mathematics or History, the goal of schooling for these children is reduced to learning English and memorisation. The most important resources that the children bring with them to schooling, their language resources, are thus rendered invisible and worthless.

The question must be asked whether middle-class English and Afrikaans speaking parents would allow a system where their children learned, for example, isiXhosa for 2-4 hours a week in Grades 1-3 and then switched to isiXhosa only for all their instruction, learning materials and assessments from the beginning of Grade 4? Yet this is what the average child in the South African schooling system is forced to do. A deeply entrenched colonial matrix of power allows this denial of the child's right to a quality education to continue unchallenged. Furthermore, it positions multilingual teachers who use innovative bilingual strategies to support their learners as linguistically deficient, chastised for using "code-switching," and for modelling "impure" and urbanised registers of English and African languages. Ironically, while in English medium "Model C" schools teachers routinely teach the First Additional Language (FAL, frequently Afrikaans) through the medium of English, teachers in township schools are frequently berated for teaching English through the medium of an African language.

Exclusive valorising of the cultural knowledge and resources of the West is, as the preceding discussion has shown, a product of coloniality. Maldonado-Torres (2007, 262) has argued:

The Decolonial Turn is about making visible the invisible and about analyzing the mechanisms that produce such invisibility or distorted visibility in light of a large stock of ideas that must necessarily include the critical reflections of the "invisible" people themselves.

In the student protests that took place at Pretoria High School for Girls and Sans Souci Girls High School in Cape Town (among others), it was precisely the critical reflections of the "invisible" people that were made visible. Despite an overwhelming majority of African Language/English Bilingual learners at the schools, neither permitted the use of African languages on the school campus. While Pretoria Girls offers Sepedi as First Additional Language, it is not offered as a Home Language as is the case for Afrikaans and English. At Sans Souci an African language was not offered at any level, 
with students required to take Afrikaans as FAL. One of the points to emerge in the Gauteng Education Department's investigation of Pretoria High School for Girls was that the "[u]se of African languages on the school premises is not tolerated yet the other learners are allowed to express themselves in Afrikaans."

In English medium "Model C" primary schools, children whose home language is not English will generally not be admitted to Grade R or Grade 1 without proficiency in English. These children thus enter the schools as bilinguals, yet they are routinely positioned as "second language learners," and little or no support is given for the continued development of their home languages. Black learners' accents in speaking English are also often targeted as incorrect and as a source of "literacy problems" (McKinney 2017, 2013). This is despite the wealth of sociolinguistic research on the range of accents of English across the world which clearly demonstrates that there is no single correct or standard accent for the language. Unsurprisingly in South Africa, learners are often expected to assimilate to ethnolingusitic repertoires of whiteness or varieties of White South African English (WSAfE) which are considered as normative in English medium "Model C" schools (McKinney 2013).

Two examples from ethnographic fieldwork conducted by McKinney at a "Model-C" girls' school in Johannesburg illustrate the language ideologies at work and the coloniality of the language policies, both formal and tacit, of the school. On their first day of school, Grade 8 learners write an English proficiency test, as well as a mathematics test, which is used to stream, or divide, learners into classes according to their results, ranging from a "top" class to the lowest-achieving class. In explaining this procedure, the head of language made it clear that the English test carried more weight than mathematics: "Because the headmistress says when in doubt or if there is a big difference between the English and the mathematics [results] then go on the English" (Interview with the head of language). Here one sees the association of high proficiency in English with academic ability. The conflation of English competence with intelligence was further evidenced in the head of language's views on the use of African languages in the classroom:

And in an academic class, the brighter girls usually do speak English to each other and lapse into their languages less. So, I am just assuming that if you do well academically, your English is of a higher standard. I am making that assumption. ... It can be just an assumption, in a weaker class they will speak vernacular more often. (Interview with Ms Smith, Head of Language).

The assumption the teacher makes about "brighter girls" lapsing into "their language less," while girls in a "weaker class ... speak vernacular more" reinforces the reasoning underlying the streaming according to the English proficiency test that conflates good proficiency in English with intelligence. The teacher's deficit view of the use of learners' African language resources is clear in her characterisation of code switching as "laps[ing] into their languages." The valorisation of English and denigration of African languages in this "Model C" school is of course not unique, but linked to broader language ideologies in South Africa that equate educational success with English proficiency. 
Alongside this, monolingualism in English is associated with modernity and progress while African language multilingualism is relegated to "traditional culture."

Ironically, there is a certain de ja $v u$ about struggles over language and education in South Africa, evident from colonial times onwards. A glance through the Cape Colony's education commissions and government reports from the mid-1800s reveals frequent strong arguments being made for the importance of language and medium of learning - framed in relation to Afrikaans in an English-oriented schooling system. The campaign for Christian National Education, and indeed its place in apartheid schooling policies, suggests there is a hegemonic importance to language in education that goes well beyond matters of technical provision.

This leads us to consider the hegemonic role that "Model C" schools play in building the current education policy narrative of progress. Much has been written about the changes to education brought about by the first democratically elected government in South Africa after 1994. Most of this literature has been critical of the ambitious policy designs that floundered from the outset in terms of enacting the changes they envisaged. ${ }^{8}$

Post-apartheid education policies introduced a new narrative for education, based on an idealist vision of a transformed system. This policy narrative depended heavily on its vision, barely acknowledging the existing conditions in schools and classrooms let alone systematically addressing how they could be changed. In its eagerness to achieve results, the narrative glossed over the deep disparities in provision that were the legacy of apartheid and the colonial schooling system prior to that. It glossed over the complex and contested interests that are inherent in the policy process and must necessarily be negotiated in a democratic state. When problems with the new policy suite surfaced, which they did almost immediately, these were labelled as problems of policy implementation. The narrative of change included the observation that South Africa had designed "Rolls Royce policies that could not be implemented." Implicit in this discourse is the assumption that "policy formulation" and "policy implementation" are separate activities and that policies can be considered to be excellent even if they cannot be implemented. Also implicit is the inference that policy making does not need to engage with the messiness and compromises of steering change through the multiple contexts, actors and interests that make up actual schooling systems. The narrative of progress does not admit to policy deficiencies or the limits of change within existing arrangements. Instead, it continues to promise that progress towards a more equitable and better performing schooling system is possible as long as principals, teachers and students do what they are supposed to do.

Yet the evidence of what happens in actually existing schools in the system tells a different and more complex story-more aligned to the dark than the bright side of the progress narrative of modernity identified by Mignolo, Maldonado-Torres and Ndlovu-

8 This article makes no attempt to repeat the detail of this established literature. For examples see, Badat and Sayed (2014), Chisholm (2004), Christie (2008), Fleisch (2008), Motala (2005), Reddy (2005), Soudien (2012), and Van der Berg (2005, 2015). 
Gatsheni. Using test scores as flawed but available indicators, what is clear is that performance is linked to the poverty rankings of schools, to the apartheid departments that schools were formerly part of, and to the home language of students. This has been recognised in published research in South Africa for many years. ${ }^{9}$ Unsurprisingly, research on South African schooling echoes the findings in sociology of education since the US Coleman Report of 1966 that while schools may be more or less effective (and this does make a difference), the social background of students has overriding effects on their life chances beyond the school. This is a well-known point illustrated in South African research by Van der Berg (2015).

"Model C" schools are used as evidence that the education system is working, and the assumption is that all schools will at some point be the same as "Model C" in a system that assumes equality and progress. The narrative of progress does not consider that there may be limits to change within existing arrangements. It certainly does not admit that education legislation was the outcome of a negotiated settlement designed to continue the privilege of "Model C" schools which in effect undermined the chances of a single, equitable system. The determination to hold on to a "bright side" story- that positive improvements can be achieved within the system as currently structured - is well illustrated by a press release from the Department of Basic Education in January 2017 saying that despite "unacceptable levels of inequality" in the education system, "pretty much all indicators are moving in the right direction." An astounding claim follows: "South Africa has been the fastest improving education system in TIMSS between 2002 and 2015." The improvement referred to is South Africa's move from last to second last of the 41 participating countries in the Trends in International Mathematics and Science Study between 2002 and $2015 .^{10}$ The claim begs the question about the base from which improvement is measured, to say nothing of the pace of change.

\section{CONCLUSION}

Using a framework of ideas from decoloniality theorists, this paper has argued that the "Model C" student struggles of 2016 brought the power relations of coloniality into visibility. Though there are undoubtedly huge differences between the situation of black learners in "Model C" schools and those of learners in the rest of the schooling system, we suggest that the underlying logic of coloniality and modernity shapes practices in both these contexts. Learners across all these sites "breathe coloniality all the time and every day." Decoloniality theories make visible how this has come to be and the dire consequences it has for our schooling system. They also provide insights into the kinds

9 See for example Van der Berg (2005), Reddy (2005), Kanjee (2007), Christie, Butler, and Potterton (2007), Fleisch (2008), Gilmour and Soudien (2009), Frampong, Reddy, and Kanjee (2011) and Smith (2011). Others, including Spaull, have repeated these findings.

10 Trends in International Mathematics and Science Study, in which South Africa moved from last to second last position among the 41 participating countries (Singapore average 618, SA 376). 
of changes that would be required for a schooling system to work against these towards a different social imaginary.

Decoloniality theorists issue a powerful challenge to delink from the intersectional inequalities of coloniality towards a different vision of human life. As educators in South Africa, the challenge is to work towards a radically different social imaginary that breaks with the taken-for-granted forms and norms of schooling and to take active steps to change current practices. For this to be more than a utopian vision requires the difficult work of shifting existing conditions towards a different vision of what is desirable and possible.

Following the sequence of ideas set out in the earlier section of this paper, we suggest a number of points to consider. First, the distinction between colonialism and coloniality points to the need to acknowledge the limitations of the changes that were put in place after 1994. Education restructuring meant in the first instance dismantling the political and administrative arrangements of the apartheid state in order to replace the racially-based system with a single system for all. The "special provisions" for "Model C" schools in the negotiated settlement meant that the historical power relations of these schools were not fundamentally challenged. Relationships of coloniality pervade these and other schools in an education system that is fundamentally unequal in the experiences and opportunities which it offers to students. A first step in working for change is to recognise the hegemonic ways in which existing arrangements coalesce into a set of "common sense" ideas around schooling that are difficult to think beyond.

Second, and following from this, decoloniality shows the importance of questioning the rhetoric of progress that so enticingly accompanies modernity. In the case of schooling in South Africa, this means recognising there are structural limitations to what the present arrangements are able to provide for all students. The majority of schools in South Africa are rural and township schools; they are fee-free and poorly resourced. "Model C" schools may function as a hegemonic idealisation in that they represent a form of schooling that cannot actually be provided for all in the system as it exists. Delinking from a myth that all schools are able to progress towards "Model $\mathrm{C}$ " conditions if they try hard enough is an important step in developing an alternative vision.

Third, delinking requires recognition of the complex ways in which the intersectional inequalities of modernity/coloniality play out in South African schooling - the historical power differentials that continue to produce the deep inequalities are not easy to shift. In this regard, a starting point might be to take the perspective of the poorest schools in the system as a focal point for policy and to work towards changes that prioritise and value them. If policies were developed, resourced and implemented with the improvement of learning in these schools as the priority of the system, it is likely that significant shifts would result.

Fourth, delinking entails epistemic considerations with regard to curriculum. It is not possible within the space of this paper to engage fully with complex matters of what schools should teach to whom and how. Suffice it to say that decoloniality does not call for the abandonment of the Western episteme, but for the recognition 
of its situatedness and of its exclusions and partialities. Nor is there necessarily a call for the return to pristine forms of precolonial knowledge. Rather, the challenge is to acknowledge that different knowledge systems operate in entangled forms in the present world, without falling into simple relativism. Acknowledging that the current curriculum rests on notions of "powerful knowledge" culled from the Western episteme, an important step is to make space for critical reflection on how the curriculum itself operates systematically to advantage some students and disadvantage others. The postapartheid experience of curriculum change shows that there are no simple solutions or easy steps to curriculum change. Nevertheless, if the persistently unequal patterns of performance in national testing are viewed as a product of the curriculum itself, then it is possible to shift responsibility for these patterns to a systemic level and to begin a different set of conversations about curriculum and pedagogy.

Finally, in terms of language, a practical step would be to change language policies and practices in order to support the kind of translingual practices that are the norm in daily communication (Garcia and Li Wei 2014; Makalela 2015a). This could enable all children the opportunities to use their full linguistic repertoires for learning, alongside developing their proficiency in English, so that a dynamic bilingual system is resourced. While teachers' pragmatic responses to the current English-only system post-Grade 4 engage them in bilingual and multilingual teaching strategies on a daily basis, these are neither supported by appropriate learning materials nor appropriate formal assessments which are strictly monolingual (Krause and Prinsloo 2016; Probyn 2015.) South African scholars are leading the way in reconceptualising productive language use in classrooms that proceed from multilingualism and translanguaging practices as the norm (e.g. Makalela 2015b). Yet this research is ignored in the monolingual assessment regimes and learning materials imposed on schools and ultimately children. Linked to this, the hegemonic status of English, or Anglonormativity, could also be challenged by having all children learn at least one African language up to school-leaving level and having competence in an African language as a requirement for university entrance. While it may appear that these suggestions on language are not new or radical, our analysis suggests that this position underestimates the hegemonic significance of languages and their relation to power. Given the entangled inequalities of coloniality in South Africa, we suggest that shifts in the language policies and practices of schooling are an essential starting point for a programme of delinking.

\section{ACKNOWLEDGEMENTS}

Many thanks to our colleagues with whom we have discussed and developed the arguments we present here: Catherine Kell, Kate Angier, Xolisa Guzula, Soraya Abdulatief, Robyn Tyler. The paper has benefitted from the opportunities we've had to run seminars and discussions on "Decoloniality and language in education" with colleagues at the University of Cape Town, including from Education, Public Health, 
Health Education, Medicine, Engineering and the Built Environment, and Academic Development.

\section{REFERENCES}

Badat, S., and Y. Sayed. 2014. "Post 1994 South African Education: The Challenge of Social Justice." The ANNALS of the American Academy of Political and Social Science 652 (1): 127-48.

Canagarajah, A. S. 2007. "Lingua Franca English, Multilingual Communities, and Language Acquisition." The Modern Language Journal 91 (5): 923-39.

Cape Times. 2017. "Not Allowed to Speak Xhosa." Cape Times, September 2, 2017, 1.

Chisholm, L. ed. 2004. Changing Class: Education and Social Change in Post-Apartheid South Africa. Cape Town: HSRC Press; London: Zed Press.

Christie, P. 1995. "Transition Tricks? Policy Models for School Desegregation in South Africa, 1990-94." Journal of Education Policy 10 (1): 45-55. https://doi.org/10.1080/0268093950100103

Christie, P. 2008. Opening the Doors of Learning: Changing Schools in South Africa. Johannesburg: Heinemann.

Christie, P., D. Butler, and M. Potterton. 2007. Schools that Work. Ministerial Report. Pretoria: Department of Education.

Connell, R. 2007. Southern Theory: The Global Dynamics of Knowledge in Social Science. Sydney: Allen \& Unwin.

Deacon, J., P. Colditz, S. Mellet, and J. Van der Merwe. 2016. Case Law Handbook on Education: TwentyFive Cases that Helped Shape Education Law. Cape Town: Juta.

DoE (Department of Education). 1995. White Paper on Education and Training in South Africa: First Steps to Develop a New System. Pretoria: Government Gazette.

DoE (Department of Basic Education). 2017. "Black Youths Are NOT Educationally Worse Off Than 20 Years Ago.” Media Release, January 25. Accessed October 24, 2017. https://www.education.gov.za/ Newsroom/MediaReleases/tabid/347/ctl/Details/mid/5986/ItemID/4261/Default.aspx

Fleisch, B. 2008. Primary Education in Crisis: Why South African School Children Underachieve in Reading and Mathematics. Cape Town: Juta.

Frempong, G., V. Reddy, and A. Kanjee. 2011. "Exploring Equity and Quality Education in South Africa Using Multilevel Models." Compare: A Journal of Comparative and International Education 41 (6): 819-35. https://doi.org/10.1080/03057925.2011.607488

Garcia, O., and L. Wei. 2014. Translanguaging: Language, Bilingualism and Education. Basingstoke: Palgrave Macmillan. https://doi.org/10.1057/9781137385765 
Giliomee, H., and B. Mbenga. 2007. New History of South Africa. Cape Town: NB Publishers.

Gilmour, D., and C. Soudien. 2009. "Learning and Equitable Access in the Western Cape, South Africa." Comparative Education 45 (2): 281-95. https://doi.org/10.1080/03050060902920989

Grosfoguel, R. 2007. “The Epistemic Decolonial Turn.” Cultural Studies 21 (2-3): 211-23. https://doi.org/10.1080/09502380601162514

Grosfoguel, R. 2013. "The Structure of Knowledge in Westernized Universities: Epistemic Racism/Sexism and the Four Genocides/Epistemicides of the Long 16th Century." Human Architecture: Journal of the Sociology of Self-Knowledge 11 (1): 73-90.

Hamilton, C., B. K. Mbenga, and R. Ross, eds. 2012. The Cambridge History of South Africa. Volume 1: From Early Times to 1885. Africa Edition. Cambridge: Cambridge University Press.

Kanjee, A. 2007. "Improving Learner Achievement in Schools: Applications of National Assessments in South Africa." In State of the Nation: South Africa 2007, edited by S. Buhlungu, J. Daniel, R. Southall and J. Lutchman, 470-502. Cape Town: HSRC Press.

Krause, L.-S., and M. Prinsloo. 2016. "Translanguaging in a Township Primary School: Policy and Practice." Southern African Linguistics and Applied Language Studies 34 (4): 347-57. https://doi.org/10.2989/16073614.2016.1261039

Makalela, L. 2015a. "Translanguaging as a Vehicle for Epistemic Access: Cases for Reading Comprehension and Multilingual Interactions.” Per Linguam 31 (3): 15-29. https://doi.org/10.5785/31-1-628

Makalela, L. 2015b. "Moving out of Linguistic Boxes: The Effects of Translanguaging Strategies for Multilingual Classrooms." Language and Education 29 (3): 200-17. https://doi.org/10.1080/09500782.2014.994524

Maldonado-Torres, N. 2007. "On the Coloniality of Being: Contributions to the Development of a Concept." Cultural Studies 21 (2-3): 240-70. https://doi.org/10.1080/09502380601162548

McKinney, C. 2010. "Schooling in Black and White: Assimilationist Discourses and Subversive Identity Performances in a Desegregated Girls' School." Race Ethnicity and Education 13 (2): 191-207. https://doi.org/10.1080/13613321003726876

McKinney, C. 2013. "Orientations to English in Post-Apartheid Schooling: A Study of Sociolinguistic and Identity Changes amongst Adolescent Girls in Multilingual Schools." English Today 29 (1): 22-7. https://doi.org/10.1017/S0266078412000491

McKinney, C. 2017. Language and Power in Post-Colonial Schooling: Ideologies in Practice. New York: Routledge.

Mignolo, W. 2007. "Delinking: The Rhetoric of Modernity, the Logic of Coloniality and the Grammar of De-Coloniality.” Cultural Studies 21 (2-3): 449-514. https://doi.org/10.1080/09502380601162647

Mignolo, W. 2009. "Epistemic Disobedience, Independent Thought and De-Colonial Freedom." Theory, Culture and Society 26 (7-6): 1-23.

Mignolo, W. 2011. The Darker Side of Western Modernity: Global Futures, Decolonial Options. Durham: Duke University Press. https://doi.org/10.1215/9780822394501 
Mignolo, W. 2013. “On Pluriversality.” Accessed October 19, 2017. http://waltermignolo.com/onpluriversality/Motala, S. 2005. "Finance Equity in the South African Schooling System." In Governance and Finance in the South African Schooling System: The First Decade of Democracy, edited by S. Motala and J. Pampalls, 37-67. Johannesburg: Centre for Education Policy Development and Wits Policy Unit.

Ndlovu-Gatsheni, S. J. 2013. Empire, Global Coloniality and African Subjectivity. New York: Berghahn Books.

Ndlovu-Gatsheni, S. J. 2015. "Decoloniality as the Future of Africa." History Compass 13 (10): 485-96. https://doi.org/10.1111/hic3.12264

Ngũgĩ wa Thiongo. 1986. Decolonising the Mind: The Politics of Language in African Literature. London: James Currey.

Pretoria High School for Girls SGB. 2016. "Media Statement: Response to the MEC Report Issued on Friday 02/12/2016.” December 6, 2016. Accessed October 19, 2017. http://www.phsg.org.za/uploads/ cms/files/161205_pretoria_high_school_for_girls_media_statement.pdf

Probyn, M. 2015. "Pedagogical Translanguaging: Bridging Discourses in South African Science Classrooms." Language and Education 29 (3): 218-34. https://doi.org/10.1080/09500782.2014.99 4525

Quijano, A. 2007. “Coloniality and Modernity/Rationality.” Cultural Studies 21 (2-3): 168-78. https://doi.org/10.1080/09502380601164353

Reddy, V. 2005. "Cross-National Achievement Studies: Learning from South Africa's Participation in the Trends in International Mathematics and Science Study (TIMSS)." Compare: A Journal of Comparative and International Education 35 (1): 63-72. https://doi.org/10.1080/03057920500033571

Ross, R., A. K. Mager, and B. Nasson, eds. 2012. The Cambridge History of South Africa. Volume 2: 1885-1994. Africa Edition. Cambridge: Cambridge University Press.

Smith, M. C. 2011. "Which In- and Out-of-School Factors Explain Variations in Learning across Different Socio-Economic Groups? Findings from South Africa." Comparative Education 47 (1): 79-102. https://doi.org/10.1080/03050068.2011.541678

Soudien, C. 2012. Realising the Dream: Unlearning the Logic of Race in the South African School. Cape Town: HRSC Press.

Van der Berg, S. 2005. "How Effective Are Poor Schools? Poverty and Educational Outcomes in South Africa." Paper presented at the Southern African Consortium for Measuring Educational Quality (SACMEQ) International Invitational Research Conference, Paris, September 2005.

Van der Berg, S. 2015. "What the Annual National Assessments Can Tell Us about Learning Deficits over the Education System and the School Career Year." Stellenbosch Economic Working Papers: 18/15. 